Gulawentah: Jurnal Studi Sosial

ISSN 2528-6293 (Print); ISSN 2528-6871 (Online)

Vol. 5, No. 2, Desember 2020, Hal 132-138

Tersedia Online: http://e-journal.unipma.ac.id/index.php/gulawentah

\title{
Peningkatan Hasil Belajar PPKN Siswa Sekolah Dasar Melalui Penerapan Pembelajaran Time Token
}

\author{
U Utaminingsih \\ SDN Durenan 02, Jalan Gosong Durenan Madiun 63156, Indonesia \\ Email:*utaminingsih.d2@gmail.com
}

Naskah diterima: 2511/2020; Revisi: 2/12/2020; Disetujui: 9/12/2020

\begin{abstract}
Abstrak
Penelitian ini dilakukan untuk memberikan tindakan kepada siswa SD dengan pembelajaran time token dalam pembelajaran PPKN di sekolah dasar. Pembelajaran terkait dengan nilai-nilai perjuangan dalam perumusan Pancasila. Penelitian ini merupakan penelitian tindakan kelas yang dilakukan pada 13 siswa kelas IV SDN Durenan 02 Kecamatan Gemarang Kabupaten Madiun. Penelitian ini dilakasnakan dalam dua siklus tindakan. Hasil penelitian menunjukkan nilai rata-rata hasil tes pada siklus I sebesar 68,46 dan 76,15 pada siklus II. Sedangkan untuk pencapaian ketuntasan belajar individual, siklus I sebesar 69,23\% dan siklus II sebesar 92,31\%. Ada peningkatan hasil belajar siswa pada materi memahami nilai-nilai juang dalam perumusan Pancasila melalui pembelajaran time token siswa kelas VI SDN Durenan 02
\end{abstract}

Kata kunci: Time Token; Nilai-nilai Perjuangan; Pancasila; IPS SD

\section{Increased Ability to Understand the Values of Struggle in the Formulation of Pancasila through Elementary School Students' Time Token Learning}

Abstract

This research was conducted to provide action to elementary students by learning time tokens in PPKN learning in elementary schools. Learning related to the values of struggle in the formulation of Pancasila. This research is a classroom action research conducted on 13 fourth grade students of SDN Durenan 02, Gemarang District, Madiun Regency. This research was carried out in two cycles of action. The results showed that the average value of the test results in cycle I was 68.46 and 76.15 in cycle II. Meanwhile, for the achievement of individual learning completeness, cycle I was $69.23 \%$ and cycle II was $92.31 \%$. There is an increase in student learning outcomes in the material of understanding fighting values in the formulation of Pancasila through learning time token for Grade VI students of SDN Durenan 02.

Keywords: Time Token; Struggle values; Pancasila; Elementary Social Sciences

\section{Pendahuluan}

Kemajuan peradaban sebuah bangsa dan negara tidak bisa dilepaskan begitu saja dari aspek pendidikan yang diselenggarakan di negara tersebut (Khofiatun \& Ramli, 2016). Kurikulum pendidikan memuat aktivitas belajar mengajar yang dilakukan guru sebagai pendidik kepada siswa guna tercapainya target dalam bidang pendidikan, kurikulum dirumusakan dan dirancang secara sistemastis atas dasar aturan yang berlaku (Machali, 2014; Morelent, 2015). Pembelajaran tematik integratif yaitu melibatkan beberapa kompetensi dasar dari muatan materi pelajaran yang dipadukan kedalam sebuah tema, didalam kurikulum 2013 ketercapaian siswa

DOI: 10.25273 /gulawentah.v5i2.7939

Some rights reserved. 
mengacu pada semua kompetensi inti untuk mencapai SKL yang wajib dimiliki setiap siswa (Mulyadin, 2016).

PPKn merupakan salah satu materi yang diintergrasikan dalam kurikulum 2013, dimana pelajaran PPKn diberikan kepada siswa SD dengan maksud untuk memberikan pengetahuan dan pemahaman mengenai nilai dan moral yang berlandaskan pada Pancasila dan UUD 1945. Pembelajaran PPKn di SD memeliki tujuan memiliki tujuan untuk memberikan pengetahuan, pemahaman untuk mengembangkan nilai moral berlandasan pada Pancasila, UU, dan Norma yang berlaku secara individu maupun dalam bermasyarakat (Aprilia, Slameto, \& Radia, 2018). Pentingnya muatan materi PPKn diajarkan kepada siswa di jenjang sekolah dasar untuk menambah pemahaman serta pembiasaan diri dalam kehidupan sehari-hari, PPKn juga diajarkan sejak dini agar siswa memahami dan mampu melaksanakan hak serta kewajiban sebagai warga negara dengan benar (Ningsih \& Putra, 2020).

Berdasarkan informasi disekolah, siswa cenderung mengalami kebosanan dalam pelajaran PPKn hal ini dikarenakan karateristik pelajaranya yang cenderung banyak hafalan. Pembelajaran PKn yang berlangsung, juga tidak luput dari kecenderungan proses pembelajaran yang terpusat kepada guru. Kondisi demikian tentu membuat proses pembelajaran hanya dikuasai guru. Akibatnya proses pembelajaran berlangsung kurang menarik sehingga ada kecenderungan motivasi belajar PKn siswa rendah. Hal ini antara lain dapat diamati dari beberapa hal berikut: 1) siswa malas mengerjakan PR atau tugas; 2) siswa kurang memperhatikan; 3) siswa cenderung berbicara sendiri atau mengantuk. Rendahnya motivasi belajar PKn siswa ini membawa dampak lanjutan berupa: 1) siswa menjadi enggan bertanya atau menjawab pertanyaan; 2) siswa kesulitan dalam memahami materi; 3) tingkat kemampuan penerapan atau aplikasi siswa rendah; 4) siswa kesulitan mengerjakan soal. Dampak yang paling parah adalah rendahnya daya serap siswa sehingga nilai hasil belajar PKn siswa pada umumnya rendah.

Pembelajaran yang baik dan berkualitas harus juga didukung dengan kecocokan antara metode atau model pembelajaran dan materi pembelajaran. Pemilihan metode/model pembelajaran yang tepat dapat membuat siswa termotivasi untuk belajar dan dapat mengoptimalkan hasil belajar yang diperoleh siswa (Kewa, Dadi, \& Abdullah, 2020). Setiap proses pembelajaran tentunya diharapkan peserta didik memperoleh hasil belajar yang baik. Sebagaimana yang menjadi standar baik atau tidaknya hasil belajar atas dasar KKM yang telah ditetapkan sebagai patokan keberhasilan proses pembelajaran (Nurhasanah \& Sobandi, 2016). Hal ini harus menjadi perhatian dan bahan evaluasi dalam proses pembelajaran. Menurut Mølstad and Karseth (2016) hasil belajar merupakan representasi dari kemampuan dan keterampilan yang dimiliki siswa pasca kegiatan pembelajaran.

Menurut Aziz and Ratmanida (2014) dengan menerapkan pembelajaran Time Token mampu untuk meningkatkan partisipasi peserta didik, khususnya dalam bekomunikasi dan mengungkapkan pendapat. Pembelajaran IPS di Sekolah dasar dengan menerapkan model pembelajaran Time Token dapat meningkatkan keaktifan dan hasil belajar (Lazim, 2018). Menurut Ningsih and Putra (2020) penerapan Time Token dengan dibantu media audiovisual memberikan timbal balik yang positif dalam membantu membangun struktur kognitif siswa dan mampu membangun pengetahuan awal siswa untuk mengoptimalkan kompetensi pengetahuan PPKn siswa. Terkait belum optimalnya hasil belajar PKn siswa SDN Durenan 02 Kabupaten Madiun, maka sebagai upaya perbaikan guru melakukan tindakan kelas dengan menerapkan model pembelajaran Time Token sebagai salah satu alternatif pembelajaran bermakna yang bermuara pada pembelajaran yang aktif, kreatif, efektif, dan menyenangkan.

\section{Metode Penelitian}

Penelitian dilaksanakan di SDN Durenan 02 yang terletak di Desa Durenan Kecamatan Gemarang Kabupaten Madiun, pada semester I tahun pelajaran 2019/2020. Penelitian ini dilakukan dengan desain penelitian tindakan kelas. Prosedur penelitian tindakan kelas ini 
merujuk terdiri atas empat komponen pokok penelitian kelas yakni: perencanaan (planning); tindakan (acting); pengamatan (observing); dan refleksi (reflecting) (Arikunto \& Suhardjono, 2006; Samsiyah, Hanif, \& Parji, 2020). Agar diperoleh data yang akurat, penulis menggunakan sumber data lebih dari satu. Adapun sumber data yang digunakan yaitu daftar pengamatan kegiatan siswa (performent assesment) dan daftar penilaian hasil prestasi belajar siswa.

Tindakan kelas ini menggunakan model Kemmis dan Taggart (Mertler, 2009; O'Connor, Greene, \& Anderson, 2006) yang digambarkan seperti gambar 1.

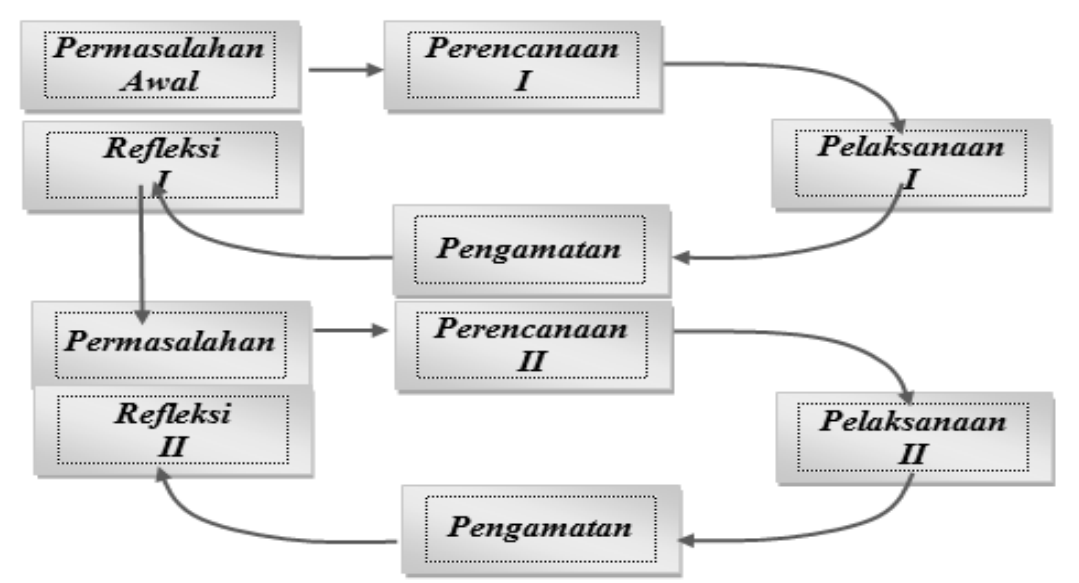

Gambar 1. Desain Penelitian Tindakan Kelas

Analisis data dalam penelitian tindakan kelas ini menggunakan analisis kuantitatif dan kualitatif (Arikunto \& Suhardjono, 2006). Terhadap perolehan hasil belajar Pendidikan Kewarga-negaraan dianalisis secara kuantitatif dengan memberikan nilai pada hasil belajar siswa. Data-data tersebut dianalisis mulai dari siklus satu dan siklus dua untuk dibanding-kan dengan teknik deskriptif prosentase. Sedangkan terhadap hasil pengamatan kegiatan siswa dianalisis menggunakan teknik deskriptif kualitatif yang digambarkan dengan kata-kata atau kalimat, yang digolongkan dalam 4 kategori, yaitu: sangat baik, baik, cukup, dan kurang. Kegiatan tersebut direncanakan dalam dua siklus. Antara siklus I dengan siklus II menggunakan indikator yang berbeda. Hasil akhir dari dua siklus dibandingkan untuk mengetahui perkembangannya, yaitu lebih meningkat atau justru menurun.

\section{Hasil dan Pembahasan}

\section{Siklus I}

Pada tahap proses rencana tindakan ini, mula-mula guru mengidentifikasikan konsepkonsep PKn pada pada materi nilai juang dalam perumusan Pancasila sebagai dasar negara yang sukar dipahami siswa. Berdasarkan masalah tersebut, sebagai acuan implementasi tindakan yang dipilih pada konsep tersebut dipelajari dan diidentifikasi, maka guru menyusun rencana pembelajaran.

Rencana pembelajaran pada siklus I sebagai berikut; 1) Guru menjelaskan tujuan pembelajaran/KD;2) Guru membagi kelas menjadi 3 (tiga) kelompok beranggotakan 4-5 anak untuk melaksanakan diskusi; 3) Guru memberi tugas pada setiap kelompok; 4) Guru memberi sejumlah kupon berbicara dengan waktu \pm 30 detik per kupon pada tiap anggota kelompok; 5) Guru meminta setiap anggota kelompok menyerahkan kupon terlebih dahulu sebelum berbicara atau memberi komentar. Setiap tampil berbicara satu kupon. Setiap anggota kelompok dapat tampil lagi setelah bergiliran dengan anggota kelompok lainnya. Setiap anggota kelompok yang telah habis kuponnya tak boleh bicara lagi. Setiap anggota kelompok yang masih memegang kupon harus bicara sampai semua kuponnya habis; 6) Guru memberi 
sejumlah nilai sesuai waktu yang digunakan tiap siswa; 7) Guru memberikan penekanan dan kesimpulan pada akhir diskusi; 8) Kegiatan pembelajaran diakhiri dengan evaluasi.

Pelaksanaan penelitian tindakan kelas (PTK) ini dilakukan pada saat kegiatan belajar mengajar di sekolah. Berdasarkan hasil evaluasi pembelajaran pada sikus I nilai rata-rata 68,46, sedangkan prosentase ketuntasan belajar mencapai 69,23\%. Evaluasi dilakukan terhadap dampak dari pemberian pembelajaran Time Token selama proses belajar mengajar terhadap hasil prestasi belajar siswa. Hasil pengamatan aktivitas siswa mmenunjukkan rata-rata 2,3 pada skor maksimal 4 atau pada tingkat 57,5\%. Hasil refleksi pada siklus I sebagai berikut: Pada siklus pertama proses kegiatan belajar mengajar tidak seperti yang diharapkan, hal ini mungkin disebabkan memerlukan waktu yang cukup lama karena setiap anggota kelompok harus berbicara satu per satu sesuai dengan kupon yang dimilikinya. Tidak cukup waktu bagi anggota kelompok yang memiliki banyak pendapat akan sulit mengutarakan pendapatnya karena waktu yang diberikan terbatas. Dengan asumasi kurang efektifan dalam proses belajar mengajar yang meliputi 2 faktor tersebut, maka hal ini diperbaiki pada siklus II.

\section{Siklus II}

Pada tahap proses rencana tindakan ini, mula-mula guru mengidentifikasikan konsepkonsep PKn pada pada materi nilai juang dalam perumusan Pancasila sebagai dasar negara yang sukar dipahami siswa.

Berdasarkan masalah tersebut, sebagai acuan implementasi tindakan yang dipilih pada konsep tersebut dipelajari dan didentifikasi, maka guru menyusun rencana pembelajaran. Rencana pembelajaran ini memuat; 1) Guru menjelaskan tujuan pembelajaran/ KD; 2) Guru membagi kelas menjadi 3 kelompok beranggotakan 4-5 anak untuk melaksanakan diskusi; 3)

Guru memberi tugas pada setiap kelompok; 4) Guru memberi sejumlah kupon berbicara dengan waktu \pm 30 detik per kupon pada tiap anggota kelompok; 5)Guru meminta setiap anggota kelompok menyerahkan kupon terlebih dahulu sebelum berbicara atau memberi komentar. Setiap tampil berbicara satu kupon. Setiap anggota kelompok dapat tampil lagi setelah bergiliran dengan anggota kelompok lainnya. Setiap anggota kelompok yang telah habis kuponnya tak boleh bicara lagi. Setiap anggota kelompok yang masih memegang kupon harus bicara sampai semua kuponnya habis. Demikian seterusnya hingga semua anggota kelompok menyampaikan pendapatnya; 6) Guru memberi sejumlah nilai sesuai waktu yang digunakan tiap siswa; 7) Guru memberikan penekanan dan kesimpulan pada akhir diskusi; 8) Kegiatan pembelajaran diakhiri dengan evaluasi. Tindakan utama pada siklus II adalah merevisi kesalahan-kesalahan konsep pada siklus I, yang mungkin menyebabkan hambatan-hambatan bagi pengembangan pemahaman siswa atas konsep-konsep yang akan dipelajari. Berdasarkan hasil evaluasi pembelajaran pada sikus II nilai rata-rata 76,15; sedangkan prosentase ketuntasan belajar mencapai $92,31 \%$. Evaluasi dilakukan terhadap dampak dari pemberian pembelajaran Time Token selama proses belajar mengajar terhadap hasil prestasi belajar siswa. Hasil pengamatan aktivitas siswa mmenunjukkan rata-rata 3,1 pada skor maksimal 4 (empat) atau pada tingkat $77,5 \%$

Pada siklus II proses kegiatan belajar mengajar sudah lebih baik dari siklus I hal ini disebabkan kelemahan-kelemahan pada siklus I sudah diperbaiki antara lain (1) dengan persiapan yang matang guru membatasi waktu berbicara setiap anggota kelompok; (2) setiap anggota kelompok yang memiliki banyak pendapat dapat meringkas atau merangkum pendapatnya dan tepat sesuai dengan waktu yang ditentukan.

\section{Pembahasan}

Berdasarkan hasil penilaian dan pengamatan siswa guru menunjukkan bahwa dengan menggunakan pembelajaran Time Token dapat membantu siswa dalam meningkatkan prestasi belajar siswa. Pembelajaran dengan Time Token dapat meningkatkan partisipasi dalam bentuk aktivitas pembelajaran bagi siswa (Nurhayati \& Utami, 2014; Perwitasari \& Abidin, 2014; 
Valentina, Jampel, \& Murda, 2013). Peningkatan partisipasi dari siswa diharpkan dapat berbanding lurus sehingga pemahaman siswa dan hasil belajar siswa juga dapat meningkat. Menurut Nurlindasari (2018) penerapan time token arends mampu meningkatkan kemampuan berpikir siswa sehingga meningkatkan hasil belajarnya. Pada pelaksanaan penelitian tindakan ini rata-rata nilai kelas mengalami kenaikan 8,15 dan prosentase ketuntasan telah memenuhi kriteria yang telah telah ditetapkan yakni $85 \%$.

Tabel 1. Perbandingan Rata-rata dan Ketuntasan Tiap Siklus

\begin{tabular}{lcc}
\hline \multicolumn{1}{c}{ Aspek Penelitian } & Siklus I & Siklus II \\
\hline Rata-rata Nilai & 68,46 & 76,15 \\
\hline Prosentase Ketuntasan & $69,23 \%$ & $92,31 \%$ \\
\hline
\end{tabular}

Untuk lebih jelas peningkatan nilai rata-rata hasil belajar dan ketuntasan belajar yang terjadi dalam penelitian ini maka akan disajikan pada gambar 2.

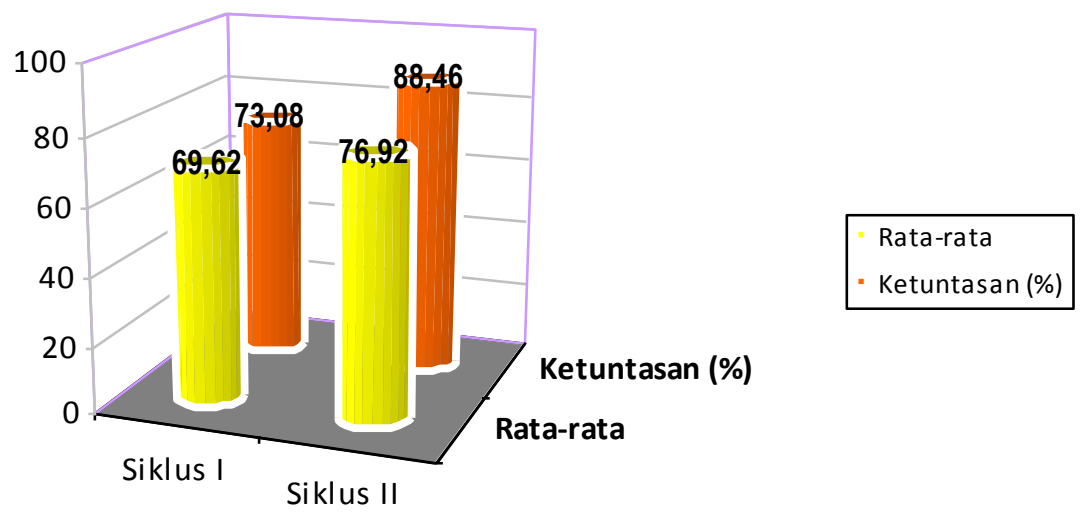

Gambar 2 Diagram Peningkatan Hasil Belajar PKn

Berdasarkan hasil observasi guru telah menerapkan model pembelajaran time token. Hal itu dapat dilihat pada substansi RPP yang disusun dan aktivitas pembelajaran yang telah dilakukan sesuai dengan langkah-langkah yang tepat sesuai petunjuk umum dalam kegiatan pembelajaran. Hasil pembelajaran akan dapat dimaksimalkan jika pelaksanakan tindakan kelas telah dilaksanakan sesuai sintaks pembelajaran (Lazim, 2018; Ningsih \& Putra, 2020; Nurhayati \& Utami, 2014). Pelaksanaan pembelajaran yang sesuai sintaks diharapkan dapat memberikan pengalaman belajar yang baik bagi siswa sehingga berdampak pada peningkatan hasil belajar siswa.

Dari hasil pelaksanaan dan pengamatan siswa dan guru cenderung lebih baik setiap siklus, maka dapat disimpulkan bahwa; Ada peningkatan hasil belajar siswa dalam materi memahami nilai-nilai juang dalam perumusan Pancasila melalui pembelajaran Time Token siswa kelas VI SDN Durenan 02 Kabupaten Madiun tahun pelajaran 2019/2020. Berdasarkan hasil pelaksanaan dan pengamatan siswa dan guru cenderung lebih baik setiap siklus, maka dapat disimpulkan bahwa ada peningkatan kemampuan memahami nilai-nilai juang dalam perumusan Pancasila siswa kelas VI SDN Durenan 02 Kabupaten Madiun tahun pelajaran 2019/2020 melalui pembelajaran time token.

\section{Simpulan}

Berdasarkan hasil penelitian yang telah dilaksanakan, maka dapat ditarik kesimpulan bahwa melalui model pembelajaran Time Token terbukti dapat meningkatkan kemampuan memahami nilai-nilai juang dalam perumusan Pancasila siswa kelas VI SDN Durenan 02 Kabupaten Madiun tahun pelajaran 2019/2020. Hal 
tersebut ditandai dari ketercapaian indikator keberhasilan penelitian tindakan kelas dan adanya peningkatan rata-rata hasil belajar PKn dari siklus I sebesar 68,46 dan 76,15 pada siklus II. Sedangkan untuk pencapaian ketuntasan belajar individual, siklus I sebesar $69,23 \%$ dan siklus II sebesar 92,31\%.

\section{Daftar Pustaka}

Aprilia, L. A., Slameto, S., \& Radia, E. H. (2018). Meningkatkan Hasil Belajar Ppkn Melalui Model Pembelajaran Numbered Heads Together (NHT) Berbasis Kurikulum 2013. WACANA AKADEMIKA: Majalah Ilmiah Kependidikan, 2(1), 85-98. doi:https://doi.org/10.30738/wa.v2i1.2530

Arikunto, S., \& Suhardjono, S. (2006). Penelitian tindakan kelas. In: Jakarta: Bumi Aksara.

Aziz, A., \& Ratmanida, R. (2014). Using A Time Token Strategy To Increase Students'participation In Speaking For Junior High School. Journal of English Language Teaching, 2(2), 30-36.

Kewa, M., Dadi, A. F. P., \& Abdullah, A. N. (2020). Peningkatan Hasil Belajar PPKn melalui Model Time Token pada Peserta Didik Kelas V SD GMIT Ende 4. Prima Magistra: Jurnal Ilmiah Kependidikan, 1(1), 102-115.

Khofiatun, K., \& Ramli, M. (2016). Peran Kompetensi Pedagogik Guru Dalam Pembelajaran Tematik Di Sekolah Dasar. Jurnal Pendidikan: Teori, Penelitian, dan Pengembangan, l(5), 984-988.

Lazim, A. (2018). Meningkatkan Keaktifan dan Hasil Belajar IPS Materi Pengertian Ruang Dan Interaksi Antar Ruang dengan Metode Time Token pada Siswa Kelas VII. A SMPN 3 Praya Tengah Tahun Pelajaran 2016/2017. JISIP (Jurnal Ilmu Sosial dan Pendidikan), 2(1).

Machali, I. (2014). Kebijakan perubahan kurikulum 2013 dalam menyongsong Indonesia emas tahun 2045. Jurnal Pendidikan Islam, 3(1), 71-94. doi:https://doi.org/10.14421/jpi.2014.31.71-9

Mertler, C. A. (2009). Action research: Teachers as researchers in the classroom: Sage.

Mølstad, C. E., \& Karseth, B. (2016). National curricula in Norway and Finland: The role of learning outcomes. European Educational Research Journal, 15(3), 329-344.

Morelent, Y. (2015). Pengaruh Penerapan Kurikulum 2013 Terhadap Pembentukan Karakter Siswa Sekolah Dasar Negeri 05 Percobaan Pintu Kabun Bukittinggi. Jurnal Gramatika, I(2), 79634. doi:https://doi.org/10.22202/jg.2015.v1i2.1234

Mulyadin, M. (2016). Implementasi kebijakan pembelajaran tematik terpadu Kurikulum 2013 di SDN Kauffman 1 Malang dan SD Muhammadiyah 1 Malang. Jurnal Edutama, 3(2), 31-48.

Ningsih, K. A. M. P., \& Putra, M. (2020). Model Pembelajaran Time Token Berbantuan Media Audio Visual Berpengaruh Terhadap Kompetensi Pengetahuan PPKn. Mimbar Ilmu, 25(3).

Nurhasanah, S., \& Sobandi, A. (2016). Minat belajar sebagai determinan hasil belajar siswa. Jurnal Pendidikan Manajemen Perkantoran (JPManper), 1(1), 128-135. 
Nurhayati, F., \& Utami, S. (2014). Peningkatan Aktivitas Belajar Melalui Model Time Token IPS Kelas IV SD Negeri 06 Pontianak. Jurnal Pendidikan dan Pembelajaran Khatulistiwa, 3(5).

Nurlindasari, E. (2018). Pengaruh Time Token Arends Terhadap Kemampuan Berpikir Kritis Mata Pelajaran IPS Kelas IV Sekolah Dasar. Jurnal Penelitian Pendidikan Guru Sekolah Dasar, 6(7).

O'Connor, K. A., Greene, H. C., \& Anderson, P. J. (2006). Action Research: A Tool for Improving Teacher Quality and Classroom Practice. Online Submission.

Perwitasari, A., \& Abidin, Z. (2014). Peningkatan Kualitas Pembelajaran Pkn Melalui Model Time Token Arends Dengan Media Audio Visual. Joyful Learning Journal, 3(1).

Samsiyah, S., Hanif, M., \& Parji, P. (2020). Peningkatan Sopan-Santun dan Disiplin melalui Tembang Dolanan pada Siswa TKIT Al Furqon Maospati Magetan. Gulawentah: Jurnal Studi Sosial, 5(1), 40-51.

Valentina, O. F., Jampel, N., \& Murda, I. N. (2013). Pengaruh Model Pembelajaran Time Token Arends Terhadap Hasil Belajar Pkn Siswa Kelas V Sd Gugus II Kecamatan Seririt. MIMBAR PGSD Undiksha, l(1). 